\title{
УСЛОВИЯ ЖИЗНИ КИТАЙСКИХ ПЕРЕСЕЛЕНЦЕВ ИЗ ПРОВИНЦИИ ХЭЙЛУНЦЗЯНА В РОССИИ В КОНЦЕ ХІХ - НАЧАЛЕ ХХ ВЕКОВ И ИХ ВЛИЯНИЕ ПОСЛЕ ВОЗВРАЩЕНИЯ НА РОДИНУ 1
}

\section{LIVING CONDITIONS OF CHINESE MIGRANTS FROM HEILONGJIAN PROVINCE IN RUSSIA IN THE LATE 19TH CENTURY AND EARLY 20TH CENTURY AND THEIR INFLUENCE AFTER RETURNING TO THE HOMELAND ${ }^{2}$}

Fu Xuejing

Summary: Heilongjiang Province is adjacent to Russia and has great geographical advantages. From the end of the 19th century, a large number of Chinese went to Russia to make a living, and the overseas Chinese in Heilongjiang were also part of them. The article briefly analyzes the living conditions of the overseas Chinese in Heilongjiang who went to Russia to make a living and their impact after returning.

Keywords: Chinese migrants from Heilongjiang province, living conditions, influence.

\author{
Фу Сюецзин \\ М.н.с., Хэйхэский университет, \\ провинция Хэйлунцзян, КНР \\ 445886690@q9.com
}

Аннотация: Расположение провинции Хэйлунцзян на границе с Россией, всегда являлось большим преимуществом. С конца 19-го века китайские переселенцы начинают массово выезжать на заработки в Россию, в том числе и из провинции Хэйлунцзян. В статье кратко анализируются условия жизни китайских переселенцев из провинции Хэйлунцзян, выехавших на заработки в Россию, и влияние, которое они оказали на развитие провинции Хэйлунцзян после возвращения.

Ключевые слова: китайские переселенцы из провинции Хэйлунцзян, условия жизни, влияние.

І. После подписания «Айхуэйского договора» и «Пекинского договора» в 1858 году цинское правительство уступило российскому правительству территорию, площадью более 1 миллиона квадратных километров, которая на севере граничила с провинцией Хэйлунцзян, на востоке - с рекой Уссури и на юге - с горным массивом Синъань Различные китайские этнические группы, которые первоначально жили в провинции Хэйлунцзян и вдоль реки Уссури, в одночасье после передачи территории получили статус китайских переселенцев на территории России.

В конце династии Цин был период «общения» между Китаем и Россией. Согласно «Айхуэйскому договору» и «Пекинскому договору», люди, живущие вдоль рек Уссури, Хэйлунцзян и Сунгари, могут вести совместную торговлю, а официальные лица обязались поддерживать Хэйлунцзяна.

1 Данная статья является результатом исследования ключевого проекта экономического и социального развития провинции Хэйлунцзян в 2020 году «Сбор, обработка и исследование исторических данных о китайских переселенцах из провинции Хэйлунцзян в России ». Номер проекта: [20532]

2 This article is the result of a study of a key project for the economic and social development of Heilongjiang Province in 2020 "Collecting, processing and researching historical data on Chinese migrants from Heilongjiang Province in Russia." Project number: [20532] 
торговцев по обе стороны пролива. Людям, осуществляющим торговлю между двумя странами в любой местности на обозначенной границе, разрешалось беспрепятственно осуществлять торговлю без оплаты налогов, а пограничные службы на протяжении всей границы были призваны осуществлять поддержку в соответствии с договором. С развитием приграничной торговли между двумя странами китайские торговцы начали выезжать в Россию для ведения торговли. Бедные крестьяне и безработные из Шаньдуня, Хэбэя и Северо-Восточного Китая попадали в России в качестве наемных или завербованных работников, либо выезжали в Россию в составе групп, отправленных на заработки.

После открытия КВЖД, Харбин стал торговым и транспортным центром рядом с приграничными городами России. С тех пор все больше людей приезжают из Харбина или через Харбин в приграничные города России для ведения торговли и выполнения работ. До и после Первой мировой войны в России не хватало рабочей силы, и Северо-Восточный Китай считался рынком труда. Через «официальную» компанию И Чэнь, Фу Я, Гуан Тэй или по заказу китайских компаний, а также через объявления о найме мастеров, которые публиковались в газетах или размещались на улицах и переулках Харбина, было завербовано большое количество китайских рабочих. В 1914 году компания Фу Е завербовала 2500 китайских рабочих в Харбине в качестве работников для горнодобывающих предприятий России; торговец Чжан Тяньчэн из чайной фирмы в Харбине завербовал 4000 китайских рабочих для строительства железной дороги в Москве. С 1916 по 1917 год 52004 человека были направлены в Россию через «Инспекцию качества» Института по надзору за здоровьем Гусянтунь в Харбине. [1] В «Истории провинции Хэйлунцзян по делам эмигрантов» указано: «В годы до и после Первой мировой войны общее количество китайских работников и китайских торговцев, покидающих страну через различные порты в Хэйлунцзяне, достигло 502621 ...»[2]

Во время Первой мировой войны правительство Бэйяна проводило политику «замены солдат солдатами». Правительство Бэйяна также направило большое количество китайских рабочих в европейские страны. В этот период в России находилось более 600000 китайских рабочих. [3] В 1917 году в России началась Октябрьская революция. Китайские рабочие в России также взяли в руки оружие и сформировали революционные группы, такие как «Китайский батальон» и «Китайский полк», чтобы сражаться плечом к плечу с русскими рабочими и солдатами, выполняя интернациональные обязательства и поддерживая Октябрьскую революцию. После войны большая часть этих людей была коллективно перевезена в Сибирь и на Дальний Восток, а часть поселилась в Европе. Некоторые уехали в Советский Союз учиться или работать техническими специалистами. Они постепенно адаптировались к местной среде проживания. Некоторые вступили в брак с местными советскими женщинами и после рождения детей предпочли остаться в Советском Союзе. Советский Союз развивал и строил сибирский регион. Из-за нехватки рабочей силы Советский Союз предложил Китаю направить в Советский Союз большое количество рабочих молодого и среднего возраста для оказания помощи в строительстве.

II. Условия жизни китайских переселенцев из провинции Хэйлунцзян в России

1. Китайские переселенцы из провинции Хэйлунцзян были активно задействованы в самых разных профессиях.

Среди китайских переселенцев, выехавших в Россию на заработки в этот период, были в основном выходцы из трех северо-восточных провинций Китая и провинции Шаньдун. Китайские переселенцы очень востребованы в качестве рабочих, и большинство из них занимается тяжелейшим трудом. До 1917 года китайские переселенцы участвовали в экономическом развитии Дальнего Востока, выполняя самые работы в самых разных сферах, включая добычу и переработку природных ресурсов, транспорт и связь, строительство, торговлю, услуги и сельское хозяйство. В основном они занимались нетехнологическим ручным трудом на шахтах, лесозаготовительных предприятиях, железных дорогах, предприятиях судоходства, рисовых мельницах, маслобойнях, мукомольных заводах и т.д., выполняли такие работы как, заготовка леса, разработка карьеров, ремонт дорог, рыбалка и охота, плотницкие работы, кладка и покраска домов, каменные работы для городского строительства и т.д. Согласно сохранившимся свидетельствам, в период царской России и революции 1905 года доля китайских переселенцев в России составляла около 70\% рабочих и ремесленников, 15\% крестьян, 10\% торговцев и 2-3\% студентов, а в государственных органах (переводчики, клерки, служащие и др.) составляли от 1 до 2\%. [4].

2. Китайские переселенцы из провинции Хэйлунцзян внесли положительный вклад в развитие Дальнего Востока.

Многие китайцы, решившие выехать в Россию на заработки, - это китайские рабочие, завербованные в Харбине. Подавляющее большинство завербованных китайских рабочих участвовали в строительстве транссибирской магистрали. В чрезвычайно суровых условиях они выполняли земляные работы, участвовали в заготовке леса, добыче полезных ископаемых и строительстве дорог, переправ и платформ. Определенный процент составляли китайские переселенцы, которые вели торговлю на территории Дальнего Востока. По статистике советского ученого Ивана Надалова, в 1879 г. в 
русском городе Уссурийск проживало 6596 китайцев, 141 из которых вели торговлю с общим оборотом 308 210 рублей в год. Есть также китайские торговцы, которые владели 133 винными магазинами, 2 кожевенными мастерскими и 8 гостиницами. [5]

На территории Дальнего Востока китайцы показали технические преимущества в ведении сельского хозяйства. Китайцы использовали свой передовой опыт ведения сельского хозяйства на Дальнем Востоке и научили местных русских крестьян более подходящим методам ведения сельского хозяйства и методам выращивания на гребнях. Унтербег, много лет проработавший в Восточной Сибири, признал, что «с точки зрения возделывания сельскохозяйственных культур китайцы и корейцы намного более продвинуты, чем русские. Они обрабатывают землю и управляют ею лучше, чем местные жители, и производят много зерна.» [6].

Кроме того, в городах, расположенных на берегах реки Амур, многие семьи нанимали китайцев в качестве прислуги. В начале XX века провинцию Хэйлунцзян и Благовещенск разделяла только река Амур, пересечь которую можно было на переправе. По реке ходили паромы, и один переход через реку стоил всего 5 копеек. В Благовещенске удобно зарабатывать деньги: на дровах можно зарабатывать 20 копеек в день. Еда тоже экономная: за 1 краюшку хлеба можно получить 4 копейки, а на обед можно съесть меньше, чем на 10 копеек. Поэтому в Россию в качестве прислуги выезжало все больше и больше людей [7]. В отраслях внутреннего водного и морского судоходства на Дальнем Востоке России китайские рабочие также играют большую роль. Китайские рабочие в морской транспортной отрасли на Дальнем Востоке в основном заняты на тяжелых работах - матросы, повара и печники.

Видно, что китайские переселенцы, выехавшие в Россию, стали важным трудовым ресурсом на Дальнем Востоке России и неотъемлемой частью экономического развития Дальнего Востока России. Они внесли положительный вклад в развитие Дальнего Востока России.

3. Китайские переселенцы из провинции Хэйлунцзян участвуют в революции.

Чжан Юнкуй, уроженец Харбина, провинция Хэйлунцзян, рано потерял мать и жил на улицах Харбина. Его усыновил русский врач. После возвращения в Россию он назвал его Василием Александровичем. В 1918 году Чжан Юнкуй стал председателем Московского отделения Китайской рабочей федерации, а 5 марта 1919 года в качестве одного из представителей Китая участвовал в первом съезде Третьего Интернационала, основанного Лениным. В 1916 и 1917 годах, Синь Цзиву, крестьянин из пригорода Харбина, выехавший на заработки в Рос- сию, Чэнь Лидэ, рабочий Харбинской швейной фабрики Чурин, Лю Фу, Цзи Шушань, Сюй Молин, Сюй Чжэньцзю и другие рабочие, прибывшие из Харбина в Россию, вступили в ряды Советской Красной Армии. Сюй Молинь воевал в составе отрядов «Тирасполь», «Первого московского рабочего полка Красной Армии» и «Киевской службы безопасности», награжден памятной медалью Октябрьской революции Советским правительством. [8]

III. Влияние, которое оказали китайские переселенцы из провинции Хэйлунцзян после их возвращения на родину

\section{1. Обогащенная пищевая культура}

Еще в годы «общения» жители Китая, уехавшие в Россию на заработки, научились готовить русские блюда, варить русские напитки и выпекать все виды хлеба. Вернувшись в Китай, переселенцы открывали магазины и фабрики, торгующие такими ароматизированными продуктами питания и напитками, что существенно обогатило местную культуру питания Китая. По словам людей, долгое время проживавших в Хэйхэ (провинция Хэйлунцзян) население которого составляло менее 3000 человек, было открыто два ресторана западной кухни в русском стиле. Ресторан «Жи Синь» был открыт Ван Кайем и компаньонами, ресторан «Дун Чжоу», открытый Дэн Хунчжу и Дэн Хуном, в котором предлагали недорогую русскую западную кухню, включая жареные стейки, пироги с барбекю, различные салаты с «обезьяньими яйцами», русские сибирские булочки, настоящий суп и домашний русский хлеб, вода, сухие закуски, джемы, соленые огурцы и т.д. В сфере русских напитков есть три цеха по производству кваса, например, фабрика лимонада «Тонгцюань» у Тиан Жунцзю, «Саньцзянская фабрика лимонада» у Ли Цзядуна, «Синьцзянская фабрика лимонада» у Сюэ Ванюаня [9].

2. Вложения в производство для строительства родного города

Китайские торговцы в России, начав получать прибыль от торговли, не забывают свою родину и родной город. Они строят дома, открывают фабрики и магазины, чтобы способствовать процветанию экономики родной страны. До 1915 года в г. Хэйхэ, провинция Хэйлунцзян, практически не было больших зданий. Позже власти города занялись составлением плана городской территории и ее обустройством. Китайские переселенцы Чжан Дексинь, Би Фэнчжи, Шао Цзунли и другие положительно откликнулись на призыв властей города и построили несколько больших зданий, которые в то время практически сформировали центр города Хэйхэ. Сегодня улица Вансу в г. Хэйхэ состоит из зданий классической русской архитектуры, выполненных в экзотическом стиле. В те же годы Би Фэнчжи был построен сегодняшний мемо- 
риальный музей китайских переселенцев. Кроме того, такие переселенцы как Ван Дяньминь, который открыл «Хэнь Юаньмао» и кирпичный завод, и Цзинь Бинхэн, построивший здание гостиницы Цин Шэнхэн, сыграли определенную роль в развитии г. Хэйхэ. В 1913 году китайские переселенцы из России Ли Цзушэн и Ван Ляньцин вернулись в г. Харбин, провинция Хэйлунцзян, чтобы построить паровую мельницу «Чэнтай». В 1915 году Чжан Боян, управляющий Гуанъюань Шэнхао во Владивостоке, приехал в Харбин, чтобы купить у русских мукомольный завод №1 в Китае, и затем построил паровую мельницу «Гуан Юаньшэн». В 1915 году Чжан Тингэ, который вел торговлю во Владивостоке, приехал в Харбин, чтобы купить у русских паровую мельницу «Ди Лецзинь», и затем построить паровую мельницу «Шуан Хэшэн». К 1919 году китайские переселенцы последовательно купили у русских торговцев восемь мукомольных заводов, на которые приходилось 47\% мощностей мукомольного производства города. Мука марки «Красный петух», производимая знаменитой паровой мельницей «Шуан Хэшэн», выпускает от 4000 до 6000 мешков в день. Мука продается в Северо-Восточном Китае и Тяньцзине и получает награды на Европейской выставке муки [10] Китайские переселенцы вернулись из России в провинцию Хэйлунцзян, чтобы внести свой вклад и в определенной степени создать промышленность, что способствовало развитию национальной промышленности и торговли.

3. Студенты, обучающиеся в России, возвращаются домой, и становятся столпами государства.

С 1906 по 1907 год генерал Хэйлунцзян Чэн Дэцюань отправил на обучение в Россию 10 человек, включая Чжу Шичан, Че Сичжэнь, Тан Баошу, Че Жэнгонг, Ван Цзуовэнь, Ван Чжунсян, Чжу Шаоян, Ли Юхуа, Лю Вэнь, Чжун Гао, которые поступили в Царский Университет Петербурга и другие университеты. Он искренне надеется, что эти студенты смогут изучать китайскую и западную культуры, иметь глубокие познания в китайских и западных науках, досконально разбираться в древнем и современном искусстве, и стать опорой для будущей внешней и внутренней политики страны. В следующем году он отправил еще троих студентов на обучение в Пе- тербург. После того, как ученики из Хэйлунцзяна приехали в Россию, они «готовились вне школы, а в остальное время года начали поступать в обычные школы». А еще через три года поступили в профессионально-техническое училище. Провинция Хэйлунцзян предоставила им официальную ежемесячную плату в размере 120 рублей (позже она была увеличена до 165 рублей) и поручила посольству Китая в России осуществлять руководство этими студентами [11].

Эти студенты оправдали ожидания, шесть лет прилежно учились в России и добились превосходных результатов. Вернувшись в Китай, они внесли положительный вклад в строительство и развитие страны. После возвращения в Китай Че Сичжэнь работал консультантом начальника Чжан Шоузэн в г. Хэйхэ и принимал активное участие в дипломатических переговорах в качестве переводчика. Чжу Шаоян был послом в Финляндии и других странах. Хотя количество студентов, обучающихся в России в этот период, было не так много, как в Европе, Америке и Японии, тем не менее, они вырастили для современного Китая группу местных чиновников, владеющих русским языком, а также сыграли положительную роль в образовании и переводах русский язык.

\section{ЗакАючение}

Поскольку провинция Хэйлунцзян территориально расположена в непосредственной близости к Дальнему Востоку России, и организована транспортная инфраструктура, большое количество жителей Китая выезжали на заработки в Россию. Они занимались разными видами занятий на Дальнем Востоке, и их упорный труд стал неотъемлемой частью экономического развития Дальнего Востока России. Они внесли положительный вклад в развитие Дальнего Востока России. Некоторые китайские рабочие взяли в руки оружие и участвовали в революционной борьбе вместе с русскими рабочими и солдатами и внесли свой вклад в победу революции. В то же время китайские переселенцы из Хэйлунцзяна, также оказали положительное влияние на экономическое развитие и строительство своего родного города после возвращения в Китай.

\section{ЛИТЕРАТУРА}

1. Под редакцией Харбинского краеведческого комитета. История Харбина 33 Гражданские дела и зарубежные китайские дела [М]. Харбин: Народное издательство Хэйлунцзяна, 1994.10: 242

2. Нин Яньхун. История китайских переселенцев в России [М]. Пекин: Народное издательство, 2015.08: 19.

3. Хао Шичан, Ли Ячэнь. Рукопись истории образования в Советском Союзе [М]. Харбин: Хэйлунцзянское педагогическое издательство, $2001.03: 100$.

4. Составлено Исследовательским рабочим комитетом городского комитета Хэйхэ провинции Хэйлунцзян. Сборник литературных и исторических данных Хэйхэ 8-й сборник исторических данных Китайского моста в России. Исследовательский рабочий комитет по литературе и историческим данным городского комитета Хэйхэ провинции Хэйлунцзян провинции Хэйлунцзян Народная политическая консультативная конференция Китая, 1991.08: 79.

5. Иван Надалов: «Краткое изложение статус-кво Северного Уссури» [M]. Шанхайское народное издательство. 1975: 104. 
6. Унтербег. Перевод отдела исследований русского отделения университета Хэйлунцзян. «Провинция Биньхай (1856-1898)» [M]. Коммерческое издательство , 1980: 122.

7. Нин Яньхун. История китайских переселенцев в России [М]. Пекин: Народное издательство, 2015.08: 84.

8. Хун Цихоу. Любовь к детям: голос китайских переселенцев в Харбине. Харбин: издательство Харбина, 1989. 12: 66

9. Под редакцией Хэйхэского муниципального комитета рабочего комитета по исследованию культурно-исторических материалов провинции Хэйлунцзян. Хэйхэ культурно-исторические материалы, серия 8: Избранные исторические материалы о Китайском мосту в России. Хэйхэский муниципальный комитет НПКСК, 1991.08: 85.

10. Хун Цихоу. Любовь к детям: голос китайских переселенцев в Харбине. Харбин: издательство Харбина, 1989. 12: 64.

11. Хао Шичан, Ли Ячэнь. Рукопись истории образования в Советском Союзе [М]. Харбин: Хэйлунцзянское педагогическое издательство, $2001.03: 21$.

(ㅇ Фу Сюецзин (445886690@qq.сот).

Журнал «Современная наука: актуальные проблемы теории и практики»

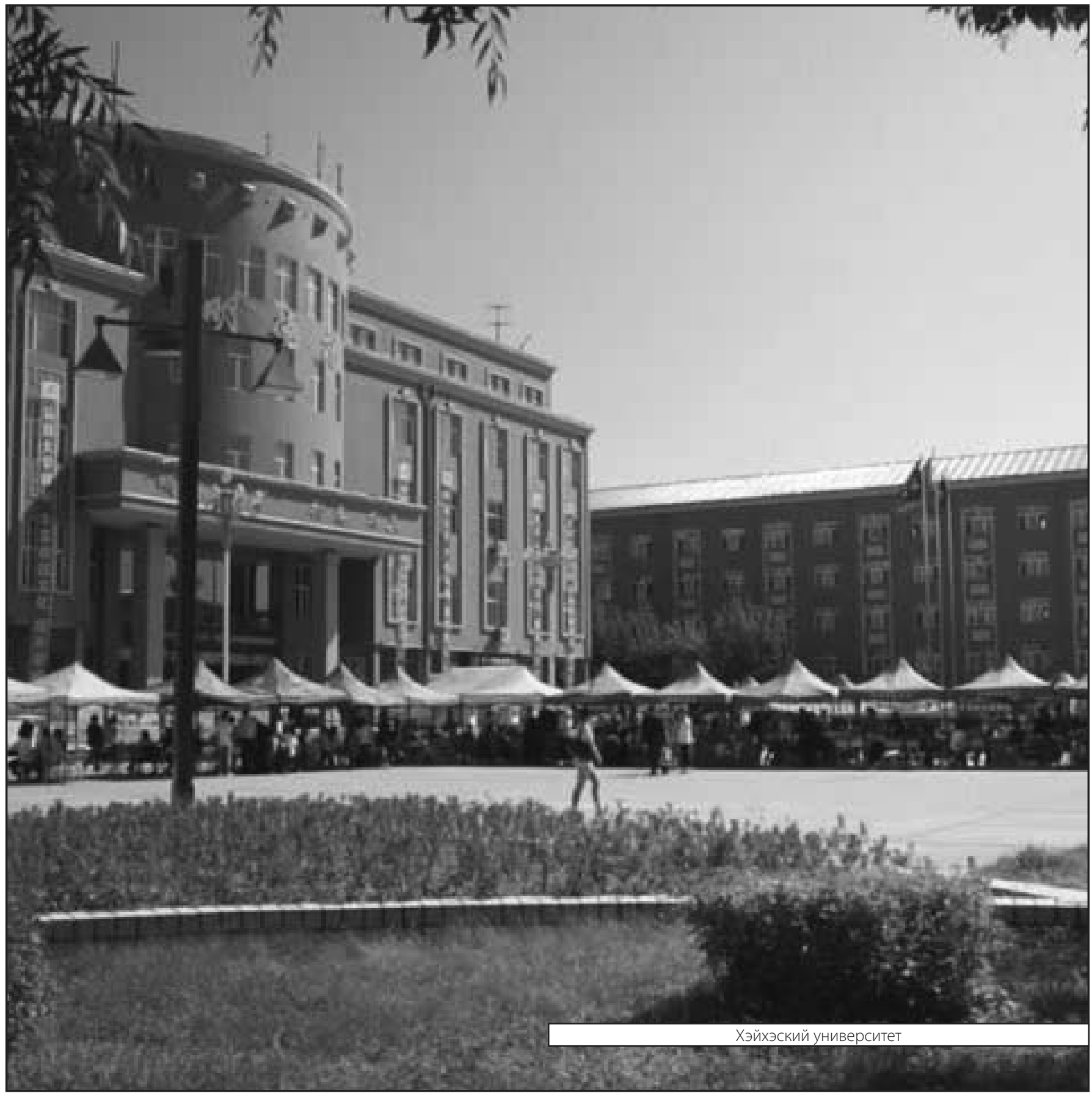

